\title{
Israel's blood policy causes furor
}

The recent revelation that the Israeli blood bank was discarding blood donated by Ethiopian Jewish immigrants caused an uproar throughout the country, leading to one of the most violent demonstrations in the country's history. But the vast majority of physicians who spoke publicly on the issue said the policy was medically justified because of the high rate of HIV infection in the Ethiopian community.

"Clearly, from a medical standpoint, there is no question the policy was correct. It would apply to any other high-risk group in Israel, and it has nothing to do with race or skin color," Mordechai Halperin, an expert on medical ethics and director of International Medical Services told Nature Medicine. He was referring to accusations by Ethiopian Jewish leaders that the policy was an act of discrimination against the dark-skinned African Jews.

"Is there a doubt that the blood bank has the responsibility to ensure the safety of Israelis blood supply? The ques-

tion is only how is it preferable to present this to the high-risk group in the least insulting way," Halperin added.

The Ethiopian blood affair broke when the newspaper Maariv reported in late January that nearly all the blood collected from Ethiopian Jews was being destroyed without the donors' being informed. The policy, never stated in writing, was adopted by the blood bank several years ago after the first immigrants arrived from Ethiopia. More than 20,000 Ethiopian Jews were brought to Israel in two spectacular airlifts in 1984 and 1991, and the rest immigrated in their wake.

The disclosure that their blood was being surreptitiously destroyed proved to be a last straw for a community already plagued by severe social and economic problems and a bitter dispute with the Israeli religious establishment, which has questioned their Jewish identity. On 28 January, an estimated 10,000 Ethiopian Jews staged a violent protest at the Prime Minister's office, in the course of which about 70 demonstrators and police were injured.

The affair prompted the Ministry of Health to release the statistics - until then never publicly announced - leaders and various commentators. An editorial in the English-language daily Jerusalem Post referred to it as a symptom of "insufferable condescension which has afflicted relations between veteran Israelis and newcomers from less developed countries." Shlomo Maayan, head of the AIDS clinic at Hadassah University Hospital, said on

IMAGE
UNAVAILABLE
FOR
COPYRIGHT
REASONS

according to which the number of HIV carriers among Ethiopian Jews is about 50 times as high as that in the general population. There are about 500 HIV carriers among the 60,000 Ethiopian Jews living in Israel, and about 800 in the rest of the population, which totals some five and a half million.

Halperin, the medical ethics expert, said the release of the statistics caused Ethiopian Jews more harm than the policy to destroy their blood. "We are talking about a stigmatization of an entire ethnic group, and it was caused not by the discrete, justified behavior of the blood bank, but by a newspaper looking for a scoop," he said. [Why the blood bank did not simply test the donated blood for HIV was not clear.]

But it was precisely the secrecy with which the destruction of blood donations was handled that drew the greatest fire from Ethiopian Jewish the radio that the correct approach would have been to offer Ethiopian Jews the option to exclude themselves from blood donations, just as other potential donors have the option of excluding themselves on the grounds of being homosexual or drug addicts.

Meanwhile, Health Minister Ephraim Sneh ordered that all blood donations from Ethiopian Jews be frozen until the committee set up by the prime minister to look into the grievances of the Ethiopian Jewish community, including the handling of donated blood, finishes its investigations. However, most Ethiopian Jews are probably too outraged by the affair to offer their blood for donation any time soon. In fact, blood bank officials expressed concern that donations from the general population may decrease.

LUBA VIKHANSKI Israel 